\title{
脳性麻痺片麻痺患者における非麻痺側の歩行分析評価
}

\author{
福 田 一* 柳 園 賜一郎* 山口 和 正 $^{*}$
}

\section{Gait Analysis Evaluation of Uninvolved Side in Patients with Hemiplegic Cerebral Palsy}

Hajime Fukuda*, Taiichiro Yanagizono*, and Kazumasa Yamaguchi

\begin{abstract}
脳性麻痺は発達早期の脳の異常病変により運動障害をきたし，痤性，筋力低下，反射京進などの病態を 呈する. 多くの脳性麻痺片麻痺では片側の優位な運動障害があるだけではなく，反対側の運動機能も少な からず障害される．脳性麻痺片麻痺患者の麻痺側に関する歩行分析の報告は多数あるが，非麻痺側に関す る報告はほとんどない。今回我々は手術治療を行っていない脳性麻痺片麻痺患者 12 例を対象に評価を行つ たので文献的考察を加え報告する。性別は男性 4 例, 女性 8 例，年齢は 9 歳 10 ケ月から 22 歳 4 ケ月，平 均年齢 14 歳 6 ケ月であつた。アニマ社製三次元動作分析装置 MA2000，フォースプレートMG1090 を用 いて運動力学・運動学的評価を行った。脳性麻痺片麻痺患者の非麻痺側では正常歩行者と比べ運動学的評 価では股, 膝, 足関節において可動域の増加や特徵的な角度変化パターンを認める症例が存在した. また, 非麻痺側の歩行に機能的脚長差が影響を及ぼしている可能性が示唆された.
\end{abstract}

Cerebral palsy causes dyskinesia such as spasticity, muscle weakness, and hyperreflexia due to the early development of cerebral aberrant lesion. Hemiplegic cerebral palsy patients have unilateral dominant dyskinesia and few disorders at the contralateral side. There are many reports of gait analysis evaluation of the involved side of hemiplegic cerebral palsy patients, but there are few reports about the uninvolved side. We evaluated 12 hemiplegic cerebral palsy patients who did not undergo surgical therapy. Adding discussion from literature, we report them below. The patients consisted of four males and eight females. Average (age was 14 years and six months) (range: 9 years and 10 months to 22 years and 4 months). Three-dimensional gait data were collected with the ANIMA motion analysis system (MA2000). Four force plates (MG1090) were used for kinetic analysis. When we compared the non-paralysis side of the cerebral palsy patients with normal gait, kinematic evaluation showed increase in range of motion in hip, knee, ankle and characteristic angle change patterns in some of the patients. In addition, it was suggested that functional leg length discrepancy has an influence on gait in the uninvolved side of cerebral palsy.

Key words : cerebral palsy (脳性麻痺), hemiplegia (片麻痺), uninvolved side (非麻痺側), gait analysis（歩行分析）

は じめに

脳性麻痺片麻痺患者の麻痺側に関する歩行分析評価 の報告は多数あるが, 非麻痺側についてのものは少な い. 今回我々は手術治療を行っていない脳性麻痺片麻 痺患者 12 例を対象に評価を行ったので, 文献的考察 を加え報告する。
対象と方 法

対象は脳性麻痺片麻痺患者の非麻痺側 12 肢である. 男性 4 例, 女性 8 例, 年齢は 9 歳 10 ヶ月から 22 歳 4 ケ月, 平均 14 歳 6 ケ月, 非麻痺側は右 3 例, 左 9 例であった. GMFCS レベルは全例 1 で, 1 例で日常 生活は短下肢装具使用していたが，検査は全例裸足で 行つた.

\footnotetext{
* 宮崎県立こども療育センター Miyazaki Prefectural Center for Handicapped Children, Miyazaki, Japan
} 
運動学的データはアニマ社製三次元動作分析システ ム MA2000, 運動力学的データはフォースプレート MG-1090 を用いた．検査は自由歩行で行い，最低 3 ストライドを採取して正規化し, 当センターで得られ た正常データ1) と比較検討した. あわせて検査前の立 位計測データより脚長を三次元的に計測した. 脚長の 計測は（図 1）に示すように，上前腸骨棘から腓骨外 果 (実線(1)), 上前腸骨棘から第五中足骨頭（点線(2) のマーカー間距離をそれぞれ計測し，非麻痺側から麻 痺側を引いた值を脚長差とした。歩行周期は Initial contact (以下 IC) から Terminal swing までを 8 相 の sub phaseに分けて評価した.

$$
\text { 結果 }
$$

時間距離因子では，正常と比較して歩行速度，スト ライド長，歩調の減少を認めた（表 $1 \mathrm{a}$ ）。また非麻 痺側では正常に比較して, 歩行周期中に立脚期の占め る割合が増加していた（表 1 b).

運動学的評価では, 足関節角度変化において立脚期 の 2 峰性底背屈パターンが 12 例中 7 例にみられた (図 $2 \mathrm{a}$ ). 膝関節角度変化では立脚期の屈曲増加, 特 に IC 時の屈曲角度の増加が 12 例中 9 例に見られた (図 2 b). 股関節角度変化では遊脚期最大屈曲角度の 増加が 12 例中 11 例に見られた（図 $2 \mathrm{c}$ ).

運動力学的評価では, 足関節パワーにおいて立脚期 のパワー吸収の増加を 12 例中 5 例に認めた（図 $2 \mathrm{~d}$ ).

$$
\text { 考察 }
$$

$\mathrm{Gage}^{3)}$ はその著書の中で片麻痺非麻痺側での代償 運動の中で, vaulting は最もよく使われる機構の 1 つであると述べている. Cimolin ら²) は非麻痺側の特 徵として, 立脚期の延長, 足関節角度変化の二峰性, IC 時膝関節屈曲角度増加, 遊脚期の最大股関節角度 増加, 立脚期足関節パワー吸収増加を挙げている. 今 回の評価ではこれらの特徵を示したのは, それぞれ 12 例中 11 例, 7 例, 9 例, 11 例, 5 例であつた.ま たそれらの機序について, 彼らは, 麻痺側での支持性 不安定のため非麻痺側の立脚期を延長して体重の支持 を行うとしており，立脚時間を増やすため，立脚期に おける脛骨前進を下腿三頭筋の遠心性収縮により抑制 されるようコントロールするため，また麻痺側の立脚 期後半に骨盤前傾が起こるためとしている.

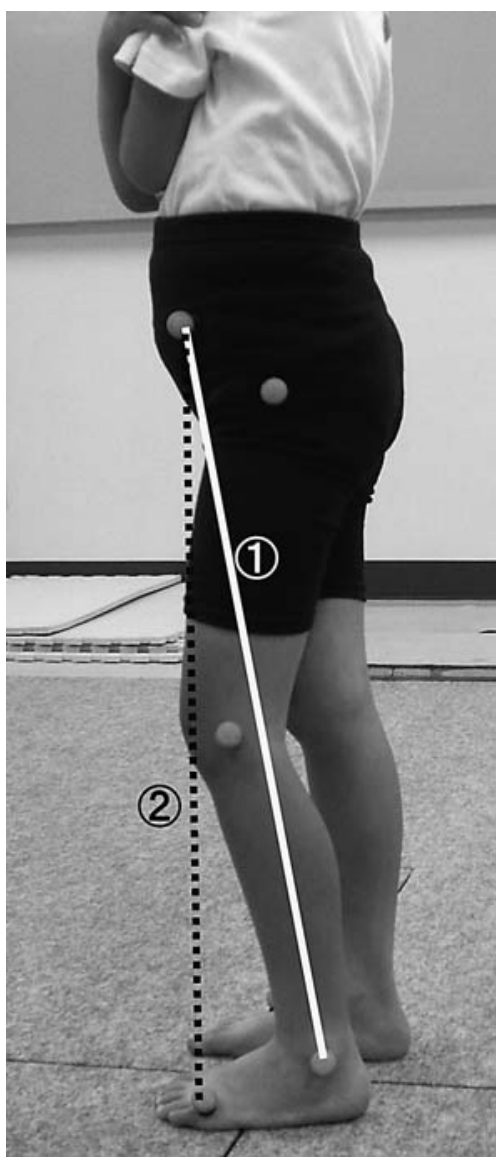

図 1 脚長計測法

上前腸骨棘～腓骨外果（実線(1)），上前腸骨棘 ～第五中足骨頭 (点線(2)，のマーカー間距離 をそれぞれ計測し, 脚長差 $(\mathrm{cm})=$ 非麻痺側脚 長 $(\mathrm{cm})$ 一麻痺側脚長 $(\mathrm{cm})$ とした.

\begin{tabular}{|c|c|c|}
\hline & 正常 & 片麻痺 \\
\hline 歩行速度 $(\mathrm{m} / \mathrm{s})$ & 1.16 & 0.92 \\
\hline ストライド長 (m) & 1.18 & 1.08 \\
\hline 歩調（歩数/分） & 118.46 & 109.01 \\
\hline & 正常 & 非麻痺側 \\
\hline 立脚期（\%） & 60.0 & 63.3 \\
\hline 遊脚期（\%） & 40.0 & 36.2 \\
\hline
\end{tabular}

表 1 

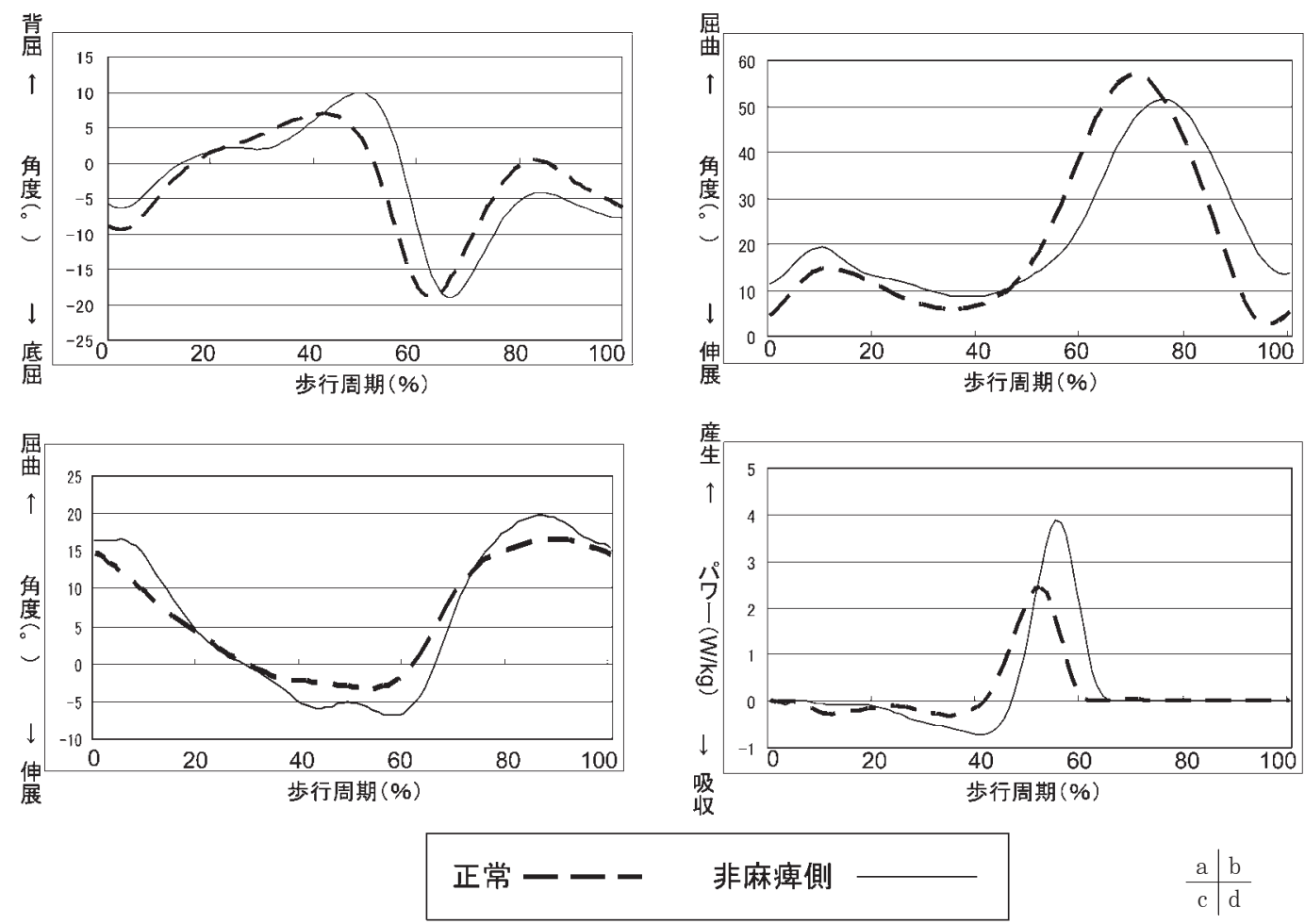

図 2 運動学的評価, 運動力学的評価 それぞれのグラフで以下の変化が認められた

（a）足関節角度変化：立脚期の 2 峰性底背屈パターン

(b) 膝関節角度変化 : 立脚期の屈曲増加, 特に IC 時の屈曲角度の増加

(c) 股関節角度変化 : 遊脚期最大屈曲角度の増加

（d）足関節パワー：立脚期のパワー吸収の増加

脚長差と歩行パターンについて Allen ら ${ }^{1)}$ は非麻痺 側が長い症例が殆どであるとした上で，骨盤の高さで 対称にするために非麻痺側の股・膝を屈曲して非麻痺 側の長さを減じるとしている。 また，Kaufman" 脚長差のある場合，短い方を長くする代償として，骨 盤側傾, 股関節外転, Mid stance での膝関節伸展, Vaulting, 尖足歩行を, 長い方を短くする代償とし て, 骨盤側傾, 分䞟し歩行, 股 - 膝関節屈曲増加, 足 関節背屈増加をあげ，脚長差のある場合患者によって これらの代償を織り交ぜて等長化をはかっているとし ている. また，脳性麻痺について書かれたほとんどの 文献では脚長は麻痺側が短いということを前提として いる. 今回機能的脚長差として立位計測でより接地面 に近い, 第五中足骨頭のマーカーと上前腸骨棘のマー
カー間距離（図 1 点線(2)）での脚長差を計測すること で, 歩行中の脚長差により近い值が得られると考えた. 当センターでは脚長として SMD (spina malleollar distance）を用いているが，これに近い值であると考 えられる上前腸骨棘のマーカーと腓骨外果のマーカー 間距離（図 1 実線(1)）では脚長差が正の值，つまり麻 痺側が短い症例の中で，上前腸骨棘のマーカーと第五 中足骨頭のマーカー間距離（図 1 点線(2)）での脚長差 が負の值, つまり麻痺側が長い症例が 3 例みられた.

股, 膝関節の屈曲拘縮により麻痺側が短いように見え ても, 尖足変形が強い場合, 機能的脚長では麻痺側が 長くなっているためであると考えられた．また，機能 的脚長差がマイナスを示した，つまり麻痺側が長い 4 例全てで, 非麻痺側の足関節角度のグラフにおいて短 
い方を長くする代償である Vaulting を表す二峰性の 底背屈パターンを示した．これより非麻痺側の歩行に は機能的脚長差が影響を及ぼしている可能性が示唆さ れた。

\section{参 考 文 献}

1) Allen, P.E., et al.: Abnormalities in the Uninvolved Lower Limb in Children with Spastic Hemiplegia: the Effect of Acutual and Functional Leg-Length Discrepancy. J. Pediatr. Orthop., 20 : 88-92, 2000.
2) Cimolin, V., et al.: Gait strategy of uninvolved limb in children with spastic hemipleagia. Europa Medicophysica, $43: 1-8,2007$.

3) Gage, J.R.: The Treatment of Gait Problems in Cerebral Palsy A Qualitative Description of Normal Gait, pp.316-328. Edited by Gage, J.R., London, Mac Keith Press, 2004.

4) Kaufman, K. R., et al.: Gait Asymmetry in Patients with Limb-Length Inequality. J. Pediatr. Orthop., $16:$ 144-150, 1996.

5）吉川大輔ほか：正常小児歩行の検討～三次元歩行分析 装置を用いて〜。整外と災外，56(1)：128-131，2007. 